whole is admirably illustrated with pen-and-ink sketches by R. A. Richardson, his pintails, showing a duck and drake floating on still water, being a particularly satisfying picture.

As we have said, the early part of the book is that devoted to general observations, and it affords much interesting reading; for example, the account in Chapter 3 of migration movements of sea. birds. The author describes how on March 22, 1932, a warm and sunny day, he watched from Gurnard's Head for five hours an immense stream of birds. "Guillemots and razorbills, the former predominating, kept passing at speed low over the sea in flocks of 100 to 200 birds... they were travelling when I came on the scene and still travelling when I was obliged to leave." Gannets, shearwaters and herring gulls also passed, and the author wonders "what was the meaning of this vast 'migrational' movement? The gannets and shearwaters were travelling away from their breeding stations off the Welsh cosst." Two other especially interesting chapters are those on the chough-with particular reference to its decrease-and the Montagu's harrier, with its history of the vicissitudes of certain individusls.

Frances PitT

The Spell of the Honey Bee

By W. Eric Kelsey. Second edition, revised. Pp. $\mathbf{x i}+274+49$ plates. (London: Chapman and Hall, Ltd., 1947.) 18s. net.

THE first edition of this book appeared in 1945 and it was rapidly exhausted. This in itself is a tribute to its merits and that it has fulfilled a need. The author is to be congratulated on the publication of a second edition so soon afterwards and, in his revision, he has taken the opportunity of rewriting the chapter dealing with bee diseases. The book is one of the most attractive bee-keeping manuals we can recall. The essentials of the craft are explained with a freshness of style that is one of the book's special attractions. Also, its value is enhanced by the copious series of half-tone plates, some of which are of exceptional merit. The working drawings of hives and appliances are an additional feature that makes the text easy to follow. Written as a manual for beginners, and with the idea of producing efficient bee-keepers, nevertheless the more experienced will find much that is of interest within its pages. It is obviously outside the scope of the author to discuss the scientific aspects of the bee in any but very general terms and, although he may be a little weak on some parts in this field, the fault scarcely detracts from the merits of the book as a whole.

I Bought a Farm

By Roy Genders. Pp. $112+8$ plates. (Worcester : Littlebury and Co., Ltd., n.d.) 10s. 6d. net.

W HEN an author buys a farm and sets about working it for profit, what more natural than that he should proceed to record the ups and downs of his first year's operations for publication. $\mathbf{M r}$. Genders, released from the R.A.F. after the War, purchased Holly Gate Farm. It was an upland Derbyshire holding of about 78 acres with an ancient but substantial homestead and buildings in a very poor state of repair. In any circumstances a new start in a farm is an anxious business, but the year 1946-47 was a nightmare for any farmer, experienced or otherwise, for one of the wettest harvests on record was followed by a very severe winter. In this book we follow the day-to-day struggle of the author and his two men to make good in the face of great difficulties. A few useful sidelines, such as mushroom growing and dog breeding, made a useful contribution to the enterprise. The story ends on a note of quiet optimism. The account is written in a conversational, almost gossipy style, and will commend itself to the general public rather than to the body of farmers, who will already be familiar with much of the technical information, and will also have experienced all the hazards, hitches and satisfactions there recorded.

\section{Students' Handbook to Fertilizers and Soils}

By L. T. Lowe. Edited by G. H. Purvis. (Published for the Monmouthshire Institute of Agriculture.) Pp. 84. (Worcester : Littlebury and Co., Ltd., 1947.) 7s. $6 d$. net.

7 HIS book aims at giving a simple account of the scientific principles of manuring and of soil science suitable for students at farm institutes. It is always difficult to write simple but accurate books in any science that are acceptable to research workers in that science. The difficulty is particularly great in agricultural science, both because the scientific principles of many practical techniques are not too well understood and also because of the great scarcity of clear accounts of the present-day views held by the research workers themselves. Thus lecturers in soil science and crop nutrition in farm institutes and agricultural colleges can justly complain that they are not well served by the research institutes of Britain, and this book unfortunately illustrates the truth of this complaint.

The book suffers in the first place from a brevity so extreme that the choice of topics mentioned appears to be arbitrary, and statements of apparent facts or theories often lack very necessary qualifications. It also, unfortunately, contains a certain number of false statements or obsolete theories. But there are many places in which it gives a reasonable account of some of our present ideas on fertilizer practice and soil science.

E. W. Russell

\section{Poisons : their Isolation and Identification}

By Frank Bamford. Second $\epsilon$ dition, revised by Dr. C. P. Stewart. Pp. viii + 304. (London : J. and A. Churchill, Ltd., 1947.) $21 s$.

THIS is a book which within a relatively small compass gives a vast amount of information. The distinguishing feature of this information is its usefulness. In too many books describing processes of scientific investigation, one finds that some vital detail of technique is not mentioned, and further research is required before the technique can be successfully used. This is not true of 'Bamford'. The details given are adequate for the working out of the processes described and they bear the marks of the author having used them.

The book, however, is not a mere catalogue of toxicological processes, and much information of general interest is given; a particularly good example of this is the short chapter on drugs of addiction.

There is no mention in the section on alcohols of the effect of the passage of time after death on the concentration of alcohol found in the blood. The book is fairly well up to date, although some of the more modern industrial poisons are missing. It is a little surprising to read that chloral has almost gone out of use in modern therapeutics. This is, however, rather outside the author's true scope; within his scope this is a good book.

Edgar Rentoul 